\title{
Relationship of glucose intolerance and hyperinsulinaemia to body fat pattern in South Asians and Europeans
}

\author{
P.M.McKeigue ${ }^{1}$, T.Pierpoint ${ }^{1}$, J.E.Ferrie ${ }^{2}$ and M.G. Marmot $^{2}$ \\ Department of Epidemiology and Population Sciences, London School of Hygiene and Tropical Medicine, and \\ ${ }^{2}$ Department of Epidemiology and Public Health, University College and Middlesex School of Medicine, London, UK
}

\begin{abstract}
Summary. Type 2 (non-insulin-dependent) diabetes mellitus and insulin resistance are associated with centrally-distributed obesity. These disturbances are especially prevalent in people of South Asian (Indian, Pakistani and Bangladeshi) descent. We examined the relationship of glucose intolerance to body fat pattern in a population survey of 2936 men and 537 women of South Asian and European origin living in London, UK. In both groups glucose intolerance (defined as diabetes or impaired glucose tolerance) was more strongly associated with waist-hip girth ratio than with skinfolds or body mass index. The associations between body mass index and glucose intolerance were fully accounted for by waist-hip ratio. In European men with normal glucose tolerance fasting insulin levels were more strongly correlated with body mass index than with waist-hip ratio. Physical activity scores were lower in South Asians than in Europeans
\end{abstract}

but no statistically significant associations between glucose intolerance and low physical activity were detectable. Leisure-time physical activity scores were inversely correlated with $2 \mathrm{~h}$ insulin levels in both groups. In contrast with other studies these results suggest that a specific effect of intra-abdominal fat deposition underlies the association between glucose intolerance and obesity. The association between hyperinsulinaemia and obesity is less specific for centrally-distributed fat. When measured appropriately waist-hip ratio is the most valid anthropometric index for identifying individuals whose obesity predisposes them to glucose intolerance.

Key words: Type 2 (non-insulin-dependent) diabetes mellitus, epidemiology, ethnology, insulin, insulin resistance, obesity, anthropometry, body fat pattern, exercise.
Glucose intolerance and insulin resistance are associated with obesity and especially with a pattern of obesity in which a high proportion of body fat is deposited on the trunk and in the abdomen $[1,2]$. Both total adiposity and body fat distribution have been found to contribute independently to the risk of Type 2 (non-insulin-dependent) diabetes mellitus [3-8]. One way to elucidate these associations is to compare populations at high and low risk of developing diabetes. Prevalence of diabetes is especially high in people of South Asian (Indian, Pakistani and Bangladeshi) descent living in urban societies [9]; this high prevalence is part of a pattern of metabolic disturbances related to insulin resistance in this group [10]. In a population survey of diabetes and cardiovascular risk in South Asians and Europeans we found that the high prevalence of diabetes was accompanied by a pronounced tendency to central obesity in South Asians [11]. Mean waist-hip girth ratios were higher and trunk skinfolds were thicker in South Asian than in European men and women, without corresponding ethnic differences in body mass index or thigh skinfolds. In this paper we report a detailed anal- ysis of the relationship of glucose intolerance to body fat pattern in this survey.

\section{Subjects and methods}

\section{Data collection}

Survey design and data collection methods have been described in detail elsewhere [11]. A sample of 3193 men and 561 women aged 40-69 years was obtained from industrial workforces and general practitioners' lists in west London. In this paper only the $1761 \mathrm{Eu}-$ ropean and 1712 South Asian participants are considered. Participants attended for examination after an overnight fast. A self-administered questionnaire was completed in advance and checked at the field station by a bilingual interviewer; this included the Rose angina questionnaire [12], medical history and physical activity during work and leisure-time. A 12-lead electrocardiogram was recorded according to the Minnesota protocol [13]. For anthropometric measurements men were examined unclothed and women wearing paper under-pants only. Skinfold thicknesses were measured with calipers (Holtain, Dafyd, UK) at the following sites: triceps, subscapular, supra-iliac, anterior thigh, and supra-patellar. 
Table 1. Glucose intolerance and anthropometric measurements by sex and ethnicity

\begin{tabular}{|c|c|c|c|c|}
\hline & \multicolumn{2}{|l|}{ Men } & \multicolumn{2}{|l|}{ Women } \\
\hline & European & South Asian & European & $\begin{array}{l}\text { South } \\
\text { Asian }\end{array}$ \\
\hline Age (years) & \multicolumn{4}{|c|}{ Age-specific prevalence of diabetes } \\
\hline $\begin{array}{l}40-44 \\
45-49 \\
50-54 \\
55-59 \\
60-64 \\
65-69\end{array}$ & $\begin{array}{r}7 / 280 \\
2 / 305 \\
13 / 300 \\
24 / 308 \\
21 / 279 \\
5 / 34\end{array}$ & $\begin{array}{r}34 / 336 \\
45 / 330 \\
68 / 321 \\
46 / 224 \\
48 / 121 \\
10 / 28\end{array}$ & $\begin{array}{r}1 / 34 \\
1 / 48 \\
0 / 51 \\
1 / 53 \\
1 / 50 \\
1 / 9\end{array}$ & $\begin{array}{r}4 / 79 \\
10 / 64 \\
10 / 64 \\
9 / 48 \\
9 / 29 \\
0 / 4\end{array}$ \\
\hline & \multicolumn{4}{|c|}{ Age-standardized prevalence } \\
\hline $\begin{array}{l}I G T \\
\text { Known diabetic } \\
\text { New diabetic }\end{array}$ & $\begin{array}{l}3 \% \\
3 \% \\
2 \%\end{array}$ & $\begin{array}{r}7 \% \\
13 \% \\
6 \%\end{array}$ & $\begin{array}{l}3 \% \\
2 \% \\
0 \%\end{array}$ & $\begin{array}{l}8 \% \\
9 \% \\
6 \%\end{array}$ \\
\hline New diabetic & \multicolumn{4}{|c|}{$\begin{array}{l}\text { Age-adjusted means for anthropometric measure- } \\
\text { ments }\end{array}$} \\
\hline Height $(\mathrm{cm})$ & 174.4 & $169.7^{\mathrm{b}}$ & 161.7 & $154.6^{\mathrm{b}}$ \\
\hline Weight (kg) & 78.7 & $73.8^{b}$ & 65.8 & 64.4 \\
\hline Waist girth $(\mathrm{cm})$ & 91.1 & $92.6^{\mathrm{b}}$ & 75.7 & $83.1^{\mathrm{b}}$ \\
\hline $\begin{array}{l}\text { Abdominal dia- } \\
\text { meter }(\mathrm{cm})\end{array}$ & 21.3 & $21.9^{\mathrm{b}}$ & 17.9 & $20.4^{\mathrm{b}}$ \\
\hline Hip girth $(\mathrm{cm})$ & 97.2 & $94.6^{\mathrm{b}}$ & 98.8 & 98.2 \\
\hline Thigh girth $(\mathrm{cm})$ & 56.7 & $55.4^{\mathrm{b}}$ & 57.9 & $58.8^{\mathrm{a}}$ \\
\hline \multicolumn{5}{|l|}{ Skinfold ratios } \\
\hline $\begin{array}{l}\text { Subscapular/ } \\
\text { triceps } \\
\text { Subscapular/ }\end{array}$ & 1.65 & $2.01^{\mathrm{b}}$ & 0.88 & $1.08^{\mathrm{b}}$ \\
\hline anterior thigh & 1.42 & $1.72^{\mathrm{b}}$ & 0.57 & $0.78^{b}$ \\
\hline
\end{tabular}

${ }^{\mathrm{a}} p<0.1,{ }^{\mathrm{b}} p<0.001$ for differences between Europeans and South Asians within each sex.

IGT, Impaired glucose tolerance. Means for skinfold thicknesses, body mass index and waist-hip ratio have been published previously [11]

Waist and hip girths were measured in the standing position with a fibreglass tape $15 \mathrm{~mm}$ wide using a spring balance attached to one end to hold the tape at a tension of $600 \mathrm{~g}$. Waist was measured as the smallest horizontal girth between the costal margin and iliac crests, and hip as the circumference at the level of the greater trochanters. Thigh circumference was measured as the maximum girth around the upper thigh, with the right foot resting on a chair so as to flex the hip and knee to right angles. Sagittal abdominal diameter at the level of the iliac crest was measured in the supine position with a Harpenden anthropometer (Holtain); this measurement was included because it correlates highly with computed tomographic measurements of intra-abdominal fat mass [14]. Venous blood samples were taken in the fasting state and $2 \mathrm{~h}$ after a $75 \mathrm{~g}$ glucose load. Participants who had previously been diagnosed as diabetic and treated with diet, tablets or insulin were not asked to undergo a glucose tolerance test. Plasma glucose and serum insulin were measured as described previously [11].

\section{Statistical analysis}

Diabetes and impaired glucose tolerance were defined by World Health Organization criteria [15]: participants with previously diagnosed diabetes were included in the diabetic category. For 25 participants glucose tolerance data were missing. From the questionnaire two physical activity scores were calculated for each individual. A work activity score was derived from the frequencies of sitting, walking, and lifting heavy loads at work; unemployed and retired subjects were excluded. Leisure-time activity score was calculated as the average weekly energy expended in walking, cycling and sporting activities, including travel to work but excluding work itself. The energy cost of these activities was derived from published studies [16]. Participants with evidence of coronary heart disease were excluded from the physical activity data in this paper. Evidence of coronary heart disease was defined as electrocardiographic major Q waves (Minnesota codes 1-1 or 1-2), a physician's diagnosis of heart attack or angina, or a positive angina questionnaire. The 745 men examined at the workplace, whose metabolism may have been affected by occupational activity on the morning of the test, were excluded from the correlations between work activity score and serum insulin.

Leisure-time activity scores, body mass index, skinfolds and serum insulin were transformed to functions of the form $X^{\mathrm{c}}$ before analysis, choosing for each variable $X$ a constant $\mathrm{c}$ so that the skewness of the transformed variable was close to zero. In the tables these variables have been returned to the original units. Tests of significance for continuous variables are based on analyses of variance in least-squares regression models controlling for 10-year age group as a categoric variable. Age-adjusted means are the values predicted in these models when the age variables are held at their mean values.

Diabetes prevalence rates in each sex-ethnic group were directly standardized to the age distribution of the entire sample. Tests of significance for proportions are based on the Cochran-MantelHaenszel chi-square statistic [17], stratifying by 10-year age group. Associations of glucose intolerance with body mass index and waisthip ratio were examined in logistic regression models. Linear and quadratic terms in each obesity index were added to the model and the change in deviance was tested as a chi-square variate with two degrees of freedom. A test for equality of variances in paired samples [18] was used to compare the proportion of variance in serum insulin explained by waist-hip ratio with the proportion explained by body mass index.

Table 2. Age-adjusted means for waist-hip ratio, body mass index and serum insulin in South Asian and European men by glucose tolerance category

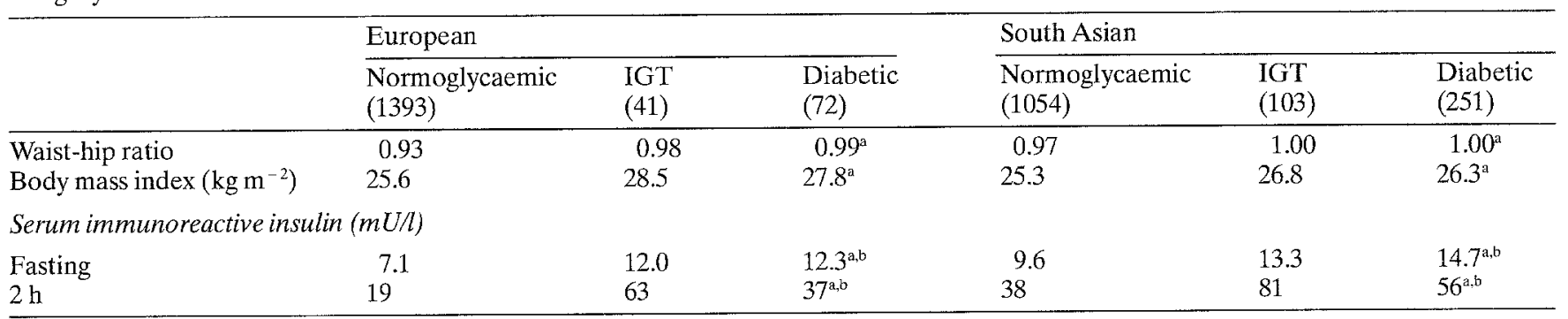

${ }^{a} p<0.001$ for differences between glucose tolerance categories within each ethnic group.

b Based on untreated diabetic men only; 33 Europeans and 101 South Asians

IGT, Impaired glucose tolerance 
Table 3. Logistic regression analyses of univariate associations between glucose intolerance and anthropometric variables, by sex and ethnicity

\begin{tabular}{llll}
\hline & \multicolumn{3}{l}{$\begin{array}{l}\text { Standardized logistic regression coeffi- } \\
\text { cients }\end{array}$} \\
\cline { 2 - 4 } & $\begin{array}{l}\text { European } \\
\text { men }\end{array}$ & $\begin{array}{l}\text { South Asian } \\
\text { men }\end{array}$ & $\begin{array}{l}\text { South Asian } \\
\text { women }\end{array}$ \\
\hline Height & 0.96 & 0.99 & $0.73^{\mathrm{b}}$ \\
Weight & $1.72^{\mathrm{d}}$ & $1.33^{\mathrm{d}}$ & $1.35^{\mathrm{b}}$ \\
Waist girth & $2.00^{\mathrm{d}}$ & $1.54^{\mathrm{d}}$ & $2.16^{\mathrm{d}}$ \\
Sagittal abdominal & & & \\
diameter & $1.99^{\mathrm{d}}$ & $1.59^{\mathrm{d}}$ & $2.17^{\mathrm{d}}$ \\
Hip girth & $1.53^{\mathrm{d}}$ & $1.17^{\mathrm{c}}$ & 0.85 \\
Thigh girth & $1.32^{\mathrm{c}}$ & $1.12^{\mathrm{a}}$ & 0.96 \\
Skinfolds & & & \\
Triceps & $1.53^{\mathrm{d}}$ & $1.15^{\mathrm{b}}$ & 1.16 \\
Subscapular & $1.94^{\mathrm{d}}$ & $1.56^{\mathrm{d}}$ & $1.89^{\mathrm{d}}$ \\
Supra-iliac & $1.29^{\mathrm{b}}$ & $1.12^{\mathrm{a}}$ & $1.67^{\mathrm{c}}$ \\
Anterior thigh & $1.10^{\mathrm{b}}$ & 1.06 & $0.76^{\mathrm{b}}$ \\
Supra-patellar & $1.28^{\mathrm{b}}$ & $1.14^{\mathrm{b}}$ & $0.67^{\mathrm{c}}$ \\
Composite indices & & & \\
Body mass index & $1.97^{\mathrm{d}}$ & $1.43^{\mathrm{d}}$ & $1.62^{\mathrm{c}}$ \\
$\begin{array}{l}\text { Waist-hip ratio } \\
\text { Subscapular/triceps ratio } \\
\text { Subscapular/anterior }\end{array}$ & $1.2 .47^{\mathrm{d}}$ & $1.81^{\mathrm{d}}$ & $3.41^{\mathrm{d}}$ \\
thigh ratio & $1.37^{\mathrm{d}}$ & $1.51^{\mathrm{c}}$ \\
\hline T & $1.76^{\mathrm{d}}$ & $1.45^{\mathrm{d}}$ & $2.26^{\mathrm{d}}$ \\
\hline
\end{tabular}

${ }^{\mathrm{a}} p<0.1,{ }^{\mathrm{b}} p<0.05,{ }^{\mathrm{c}} p<0.01,{ }^{\mathrm{d}} p<0.001$ for the association between glucose intolerance and the anthropometric variable, controlling for age.

"Relative odds of glucose intolerance associated with increase of anthropometric variable by one $\mathrm{SD}$, in a logistic regression model with age as the only other variable

\section{Results}

\section{Relation of glucose intolerance with body fat pattern}

Age-standardized prevalence of glucose intolerance (defined as impaired glucose tolerance or diabetes) was $26 \%$ in South Asians and $7 \%$ in Europeans (Table 1). In each ethnic group body mass index, waist-hip ratio and serum immunoreactive insulin levels were higher in men with diabetes or impaired glucose tolerance than in normoglycaemic men (Table 2). Compared with diabetic men, men with impaired glucose tolerance had higher $2 \mathrm{~h}$ insulin levels but similar fasting insulin levels. Because mean waist-hip ratios and body mass indices were similar in men with impaired glucose tolerance and diabetic men, these two groups were combined in subsequent analyses of the relationship between body fat pattern and glucose intolerance.

The correlations between body mass index and waisthip ratio were weaker in women than in men and weaker in South Asians than in Europeans: the coefficients were 0.68 in European men, 0.60 in European women, 0.56 in South Asian men and 0.45 in South Asian women. The correlations between sagittal abdominal diameter and waist girth ranged from 0.91 in European men to 0.87 in South Asian women. The relationships of anthropometric measures to prevalence of glucose intolerance were examined in a series of logistic regression analyses, controlling for age. European women were excluded from these analyses because of small numbers. The strongest univariate relationships with glucose intolerance were with waist girth, abdominal diameter and subscapular skinfold (Table 3). The specificity of the association between glucose intolerance and central adiposity was clearest in South Asian women, in whom thigh skinfold thicknesses were inversely associated with glucose intolerance. The associations of glucose intolerance were stronger with waist-hip ratio than with body mass index or with ratios of skinfold measurements.

When men in each ethnic group were stratified by body mass index and waist-hip ratio simultaneously, there was no independent association between body mass index and glucose intolerance (Fig.1). The numbers of South Asian women were too small for a similar direct comparison of stratum-specific prevalence rates. Logistic regression was used instead to test whether body mass index and waisthip ratio were independently associated with glucose intolerance in the three sex-ethnic groups (Table 4). When waist-hip ratio was included first in the models, body mass index made no significant additional contribution to the prediction of glucose intolerance. When body mass index was included first, the additional contribution of waist-hip ratio after controlling for body mass index was highly significant. Addition of sagittal abdominal diameter to a

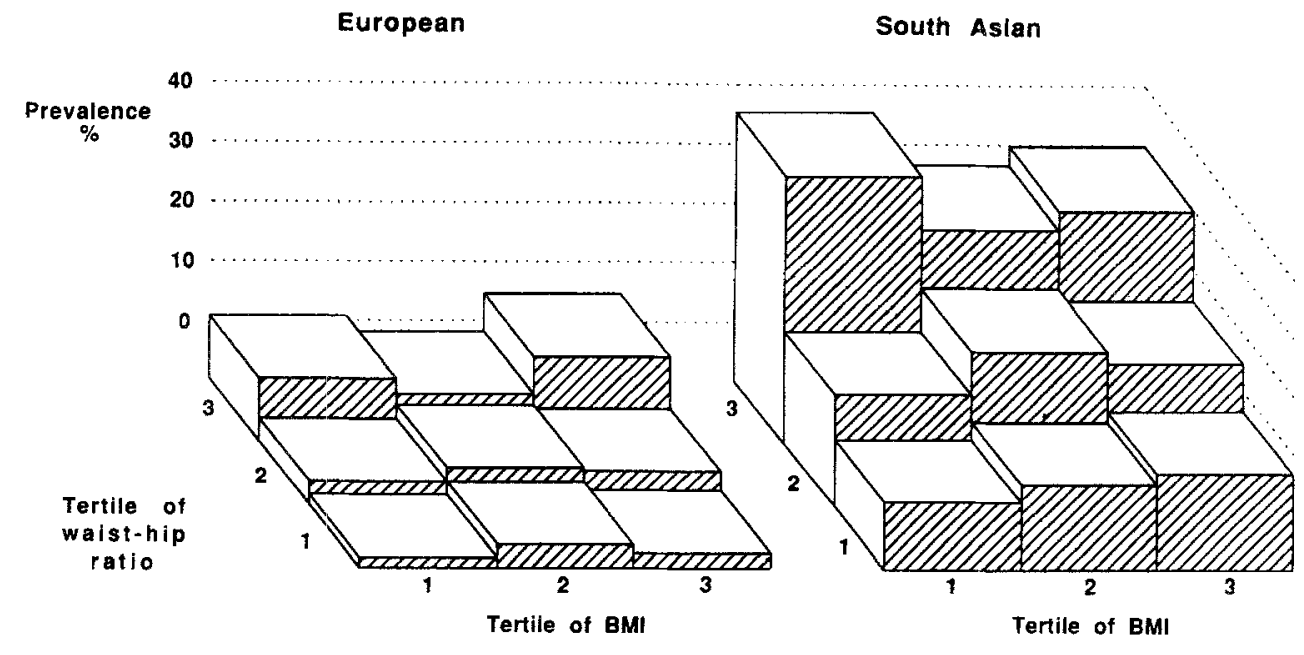

Fig. 1. Age-standardized prevalence of glucose intolerance in South Asian and European men, by tertiles of body mass index (BMI) and waist-hip ratio. Tertiles calculated separately for each ethnic group 
Table 4. Associations of glucose intolerance with waist-hip ratio and body mass index in multiple logistic regression analyses

\begin{tabular}{llll}
\hline & $\begin{array}{l}\text { Change in deviance }\left(\mathrm{X}^{2}, 2 \mathrm{df}\right) \text { associated } \\
\text { with adding linear and quadratic terms in } \\
\text { second variable }\end{array}$ \\
\cline { 2 - 3 } & $\begin{array}{l}\text { European } \\
\text { men }\end{array}$ & $\begin{array}{l}\text { South Asian } \\
\text { men }\end{array}$ & $\begin{array}{l}\text { South Asian } \\
\text { women }\end{array}$ \\
\hline $\begin{array}{l}\text { Controlling for age and } \\
\text { waist-hip ratio, adding }\end{array}$ & & \\
BMI & 2.72 & 1.43 & 4.03 \\
$\begin{array}{l}\text { Controlling for age and } \\
\text { BMI, adding waist-hip } \\
\text { ratio }\end{array}$ & & & \\
\hline
\end{tabular}

a $p<0.001$ for additional contribution of second variable. BMI, Body mass index; df, degrees of freedom

Table 5. Percent of variance in serum insulin levels in normoglycaemic subjects explained by waist-hip ratio or body mass index, after controlling for age

\begin{tabular}{llll}
\hline & & \multicolumn{1}{c}{$\begin{array}{l}\text { Waist-hip } \\
\text { ratio }\end{array}$} & $\begin{array}{l}\text { Body mass } \\
\text { index }\end{array}$ \\
\hline \multirow{4}{*}{ Men } & Percent of variance in fasting insulin & \\
\multirow{4}{*}{ Women } & European & 15.1 & $19.4^{\mathrm{b}}$ \\
& South Asian & 13.1 & 15.5 \\
& European & 21.3 & 26.9 \\
& South Asian & 17.8 & 10.7 \\
\multirow{3}{*}{ Men } & Percent of variance in 2 hinsulin $^{\mathrm{c}}$ & \\
& European & 10.5 & 9.6 \\
\multirow{3}{*}{ Women } & South Asian & 8.7 & $5.6^{\mathrm{a}}$ \\
& European & 8.2 & 5.9 \\
& South Asian & 8.6 & 4.9 \\
\hline
\end{tabular}

${ }^{\mathrm{a}} p<0.05,{ }^{\mathrm{b}} p<0.01$ for the difference between the proportion of variance explained by waist-hip ratio and the proportion explained by body mass index, using a test for equality of variances in paired samples [18].

${ }^{c}$ Difference between the $\mathrm{R}^{2}$ value for a least-squares regression model with age group as the only independent variable and the $\mathrm{R}^{2}$ value when linear and quadratic terms in waist-hip ratio or body mass index were added to the model

model including waist and hip circumference significantly improved the prediction of glucose intolerance in South Asian women $\left(\chi^{2}=5.35, p=0.02\right)$ but not in European or South Asian men. Controlling for waist-hip ratio reduced the age-adjusted odds ratio for prevalence of glucose intolerance in South Asians vs Europeans from 4.8 to 3.4 in men and from 7.1 to 3.3 in women.

\section{Relation of insulin with body fat pattern}

The correlations of obesity indices with serum insulin were examined within each sex-ethnic group, excluding subjects with diabetes and impaired glucose tolerance (Table 5). In European men the proportion of variance in fasting insulin explained by waist-hip ratio was significantly less than the proportion explained by body mass index $(p=0.007)$. In all four sex-ethnic groups the proportion of variance in $2 \mathrm{~h}$ insulin explained by waist-hip ratio was higher than the proportion explained by body mass index; only in South Asian men was this difference statistically significant $(p=0.03)$. In men adjusting for waist-hip ratio in a regression model accounted for $45 \%$ of the ethnic difference in fasting insulin and $22 \%$ of the ethnic difference in $2 \mathrm{~h}$ insulin; in women the proportions were respectively $47 \%$ and $26 \%$.

\section{Physical activity}

Age-adjusted mean leisure-time activity scores in men without evidence of coronary heart disease were lower in South Asians than in Europeans (3.0 vs $4.2 \mathrm{MJ} /$ week, $p<0.001$ ), though most men in both groups were physically inactive (Fig. 2). Work activity scores were higher in South Asian than in European men, reflecting the higher proportion of manual workers in the South Asian group. When men with diagnosed diabetes were excluded, there were no statistically significant associations between physical activity scores and glucose intolerance (Table 6). Waist-hip ratio was inversely correlated with leisure-time activity score but not with work activity score. Though statistically significant these relationships were weak and adjusting for leisure-time activity explained only $7 \%$ of the ethnic difference in waist-hip ratio. In both ethnic groups $2 \mathrm{~h}$ insulin levels in normoglycaemic men were inversely correlated with work and leisure-time activity scores.

\section{Discussion}

In comparison with Europeans, South Asians tend to accumulate fat in the abdomen and truncal region and consequently have larger waist circumferences, larger $a b-$ dominal diameters, and thicker trunk skinfolds. However, South Asian men have no more fat on the hips and thighs than have European men. South Asian women are generally more overweight than European women and also have a more central distribution of body fat. The tendency for South Asians to accumulate intra-abdominal fat without necessarily developing generalized obesity contrasts with other populations at high risk of diabetes, such as Pima Americans [19] and Nauruans [20], in whom average body mass indices are considerably higher than in populations of European origin. Although Mexican-American
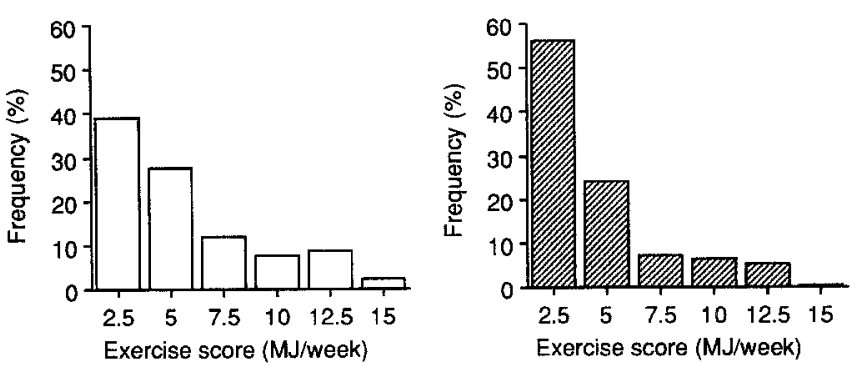

Fig. 2. Frequency distributions of leisure-time activity scores in European men (left panel) and South Asian men (right panel) without evidence of coronary heart disease 
Table 6. Relationship of activity scores with glucose intolerance, waist-hip ratio and serum insulin in men without evidence of coronary heart disease

\begin{tabular}{|c|c|c|c|c|}
\hline & \multicolumn{2}{|c|}{ European } & \multicolumn{2}{|c|}{ South Asian } \\
\hline & $\begin{array}{l}\text { Work } \\
\text { score }\end{array}$ & $\begin{array}{l}\text { Leisure } \\
\text { score }\end{array}$ & $\begin{array}{l}\text { Work } \\
\text { score }\end{array}$ & $\begin{array}{l}\text { Leisure } \\
\text { score }\end{array}$ \\
\hline & \multicolumn{4}{|c|}{ Standardized logistic regression coefficients ${ }^{\mathrm{e}}$} \\
\hline \multirow[t]{2}{*}{ Glucose intolerance } & 0.86 & 1.02 & 1.00 & $0.84^{\mathrm{a}}$ \\
\hline & \multicolumn{4}{|c|}{ Age-adjusted correlation coefficients ${ }^{\mathrm{f}}$} \\
\hline $\begin{array}{l}\text { Waist-hip ratio } \\
\text { Fasting insuling } \\
2 \mathrm{~h} \text { insulin }\end{array}$ & $\begin{array}{c}0.00 \\
-0.08^{\mathrm{b}, \mathrm{h}} \\
-0.15^{\mathrm{d}, \mathrm{h}}\end{array}$ & $\begin{array}{l}-0.14^{\mathrm{d}} \\
-0.09^{\mathrm{c}} \\
-0.15^{\mathrm{d}}\end{array}$ & $\begin{array}{c}0.02 \\
-0.05^{\mathrm{h}} \\
-0.14^{\mathrm{c}, \mathrm{h}}\end{array}$ & $\begin{array}{l}-0.10^{\mathrm{d}} \\
-0.05 \\
-0.10^{\mathrm{c}}\end{array}$ \\
\hline
\end{tabular}

${ }^{\mathrm{a}} p<0.1,{ }^{\mathrm{b}} p<0.05,{ }^{\mathrm{c}} p<0.01,{ }^{\mathrm{d}} p<0.001$ for the association.

- Relative odds of glucose intolerance associated with increase of exercise score by one $\mathrm{SD}$, in a logistic regression model with age as the only other variable. Men with previously diagnosed diabetes are excluded.

'Partial correlation of the variable with exercise score in a leastsquares regression model with age as the only other variable.

${ }^{g}$ Excluding men with diabetes or impaired glucose tolerance.

${ }^{\mathrm{h}}$ Excluding men examined at the workplace

women have a more central pattern of subcutaneous fat distribution than non-Hispanic European women, waisthip ratios in Mexican-American men and women are no higher than in non-Hispanic Europeans when allowance is made for differences in body mass index [21]. Waist-hip ratio and body mass index are strongly correlated in men, whose obesity is almost always associated with accumulation of central fat. In women the association between the quantity of body fat and its distribution is weaker, which makes it easier to distinguish the effects of these two factors. The association between glucose intolerance and central obesity appears to be stronger in South Asian women than in South Asian men; similar findings have been reported in a prospective study of Mexican-Americans [22].

Other cross-sectional [3-6] and prospective [7, 8] studies of the relationship between body fat pattern and glucose intolerance have found that both waist-hip ratio and body mass index are independently associated with glucose intolerance. In Finnish men and women aged 4574 years $[3,4]$ body mass index accounted statistically for a higher proportion of variance in $2 \mathrm{~h}$ glucose than did waisthip ratio. In Mexican-Americans [5] the association with prevalent diabetes was stronger for waist-hip ratio than for body mass index in men but not in women; among Indians in Mauritius the opposite was found [6]. In two prospective studies in Gothenburg, Sweden, waist-hip ratio and body mass index were equally and independently predictive of diabetes incidence in men aged 54 at 13.5 years of followup [7] and in women aged 38-60 at 12 years of follow-up [8] . These earlier results contrast with our unequivocal finding that, in two ethnicgroups and both sexes, waist-hip ratio accounted statistically for the entire association between weight-for-height and glucose intolerance. Our findings are more consistent with a study of Japanese men aged 40 59 years in which glycated haemoglobin levels were related to waist-hip ratio but not body mass index in a multivariate analysis [23].
Waist-hip ratio is difficult to measure reliably, and techniques may not be comparable between studies. In the Gothenburg men hip circumference was measured at the level of the anterior superior iliac spine [7], which differs from the usual measurement at the level of the greater trochanters or around the buttocks. In the Mauritian study waist was measured as the least circumference between the levels of the xiphisternum and the umbilicus [6]. The relationship of this measurement to intra-abdominal fat mass is uncertain; in some subjects it would be equivalent to measuring the girth of the lower thorax. Others have constructed indices of body fat distribution from skinfold thicknesses: the subscapular/triceps ratio has been used as a "centrality index" [22, 24]. In this study glucose intolerance was associated more strongly with waist-hip ratio than with any combination of skinfolds. If skinfold measurements are to be used to identify individuals whose body fat pattern predisposes them to develop diabetes, then an index such as the subscapular/anterior thigh ratio which contrasts upper body fat with lower body fat appears to be more valid than the subscapular/triceps ratio. The cross-sectional associations between body fat pattern and glucose intolerance may be biased by non-response and the effects of disease; confirmation of our findings will therefore depend upon long-term follow-up.

Computed tomographic measurements of total body fat and intra-abdominal fat mass correlate more strongly with body mass index than with waist-hip ratio [24-26]. Only the ratio of intra-abdominal to extra-abdominal fat is more highly correlated with waist-hip ratio than with body mass index $[25,27]$. Our findings therefore suggest that glucose intolerance is specifically associated with high ratios of intra-abdominal to extra-abdominal fat, rather than with total fat mass. This interpretation is strengthened by the observation that in South Asian women, where total adiposity and body fat distribution are only weakly associated, glucose intolerance is inversely associated with thigh skinfold thicknesses. Although waist-hip ratio accounts statistically for less than half of the South Asian/European difference in prevalence of glucose intolerance, it is possible that direct measurements of intra-abdominal/extra-abdominal fat mass ratio would account for more of this ethnic difference.

The control of body fat distribution is not understood, although the sex differences are probably determined by hormonal influences. Central obesity and hyperinsulinaemia are associated with high androgen levels in women $[28,29]$ but not in men [30,31]. It is therefore unlikely that a disturbance of sex hormone levels could account for the tendency to central obesity and insulin resistance in both men and women of South Asian descent. To explain our findings that glucose intolerance is specifically associated with central body fat distribution whereas elevated insulin levels are associated with generalized obesity also, it is necessary to postulate two distinct pathways of association: one linking glucose intolerance specifically with central adiposity, and another linking hyperinsulinaemia with generalized adiposity. Type 2 diabetes is characterized by failure to suppress hepatic glucose production and it has been proposed that this results from failure of insulin to suppress non-esterified fatty acids 
[32]. Such a mechanism could explain the specific relationship of glucose intolerance with central obesity, since intra-abdominal fat cells are resistant to insulin-mediated suppression of lipolysis $[33,34]$ and release non-esterified fatty acids into the portal circulation. This hypothesis awaits confirmation from direct measurements.

In contrast with surveys of South Asian men in Fiji [35] and Mauritius [6], no statistically significant association between glucose intolerance and low physical activity was detectable in this study. This may be because we studied only urban residents aged over 40 years, unlike the Fijian and Mauritian studies which included younger men and agricultural labourers likely to have been physically active. Although we found inverse correlations between leisure-time activity and waist-hip ratio in men, similar to those reported by others [36], there were no correlations between occupational activity and waist-hip ratio. Leisure-time activity and efforts to control obesity are likely to be part of a pattern of health-maintaining behaviour associated with high socio-economic status, whereas physically demanding occupations are generally associated with low socio-economic status. Both occupational and leisure-time activity scores in men were inversely correlated with $2 \mathrm{~h}$ insulin levels. In people with glucose intolerance elevated immunoreactive insulin levels at $2 \mathrm{~h}$ after a glucose load may be caused by loss of the acute insulin response to glucose challenge [37] or by elevated levels of proinsulin and other intermediates which cross-react with the insulin assay [38]. However, these phenomena of Beta-cell dysfunction, which may result from the toxic effects of hyperglycaemia [39], have not been demonstrated in people with normal glucose tolerance and our analyses of insulin levels were restricted to this groups. Post-glucose insulin levels correlate with steady-state measurements of resistance to insulin-stimulated glucose disposal in normoglycaemic individuals [40]; it is reasonable, therefore, to attribute the inverse correlations between $2 \mathrm{~h}$ insulin and exercise score to the relationship between physical activity and insulin sensitivity which has been demonstrated experimentally [41]. Intervention studies may help to establish whether control of obesity and maintenance of physical fitness can reduce the risk of developing diabetes in South Asian communities and in other populations at high risk of Type 2 diabetes.

Acknowledgements. This study was supported by project grants from the Medical Research Council, the British Heart Foundation and the British Diabetic Association. PMM was supported during this study by research fellowships from the Wellcome Trust and the British Heart Foundation.

\section{References}

1. Krotkiewski M, Björntorp P, Sjöstrom L, Smith U (1983) Impact of obesity on metabolism in men and women: importance of regional adipose tissue distribution. $\mathrm{J}$ Clin Invest 72: 1150-1162

2. Evans DJ, Hoffman RG, Kalkhoff RK, Kissebah AH (1984) Relationship of body fat topography to insulin sensitivity and metabolic profiles in premenopausal women. Metabolism 33: 68-75

3. Mykkanen L, Laakso M, Uusitupa M, Pyörälä K (1990) Prevalence of diabetes and impaired glucose tolerance in elderly subjects and their association with obesity and family history of diabetes. Diabetes Care 13: 1099-1105

4. Tuomilehto J, Marti B, Kartovaara L, Korhonen HJ, Pietinen P (1990) Body fat distribution, serum lipoproteins and blood pressure in middle-aged Finnish men and women. Rev Epidemiol Sante Publique 38: 507-515

5. Haffner SM, Stern MP, Hazuda HP, Pugh J, Patterson JK (1987) Do upper-body and centralized adiposity measure different aspects of regional body-fat distribution? Diabetes 36: 43-51

6. Dowse GK, Zimmet PZ, Gareeboo H et al. (1991) Abdominal obesity and physical inactivity as risk factors for NIDDM and impaired glucose tolerance in Indian, Creole and Chinese Mauritians. Diabetes Care 14: 271-282

7. Ohlson LO, Larsson B, Svärdsudd K et al. (1985) The influence of body fat distribution on the incidence of diabetes mellitus. 13.5 years of follow-up of the participants in the study of men born in 1913. Diabetes 34: 1055-1058

8. Lundgren H, Bengtsson C, Blohme G, Lapidus L, Sjöstrom L (1989) Adiposity and adipose tissue distribution in relation to incidence of diabetes in women: results from a prospective population study in Gothenburg, Sweden. Int J Obes 13:413-423

9. McKeigue PM, Miller GJ, Marmot MG (1989) Coronary heart disease in South Asians overseas - a review. J Clin Epidemiol 42: $597-609$

10. McKeigue PM, Marmot MG, Syndercombe Court YD, Cottier DE, Rahman S, Riemersma RA (1988) Diabetes, hyperinsulinaemia and coronary risk factors in Bangladeshis in east London. Br Heart J 60: 390-396

11. McKeigue PM, Shah B, Marmot MG (1991) Relation of central obesity and insulin resistance with high diabetes prevalence and cardiovascular risk in South Asians. Lancet 337: 382-386

12. Rose GA, Blackburn H, Gillum RF, Prineas RJ (1982) Cardiovascular survey methods. 2nd edn. World Health Organization, Geneva

13. Blackburn H, Prineas RJ, Crow RS (1982) The Minnesota Code: manual of electrocardiographic findings. Standards and procedures for measurement and classification. Wright, Littleton

14. Kvist H, Chowdhury B, Grangard U, Tylen U, Sjöstrom L (1988) Total and visceral adipose tissue volumes derived from measurements with computed tomography in adult men and women:predictive equations. Am J Clin Nutr 48: 1351-1361

15. WHO study group on diabetes mellitus (1985) Diabetes mellitus: report of a WHO study group. World Health Organization Technical Report Series 727. World Health Organization, Geneva

16. Passmore R, Durnin JVGA (1955) Human energy expenditure. Physiol Rev 35: 801-840

17. Landis RJ, Heyman ER, Koch GG (1978) Average partial association in three-way contingency tables: a review and discussion of alternative tests. Int Stat Rev 46: 237-254

18. Armitage P, Berry G (1971) Statistical methods in medical research. Blackwell, Oxford, pp 165-166

19. Knowler WC, Pettitt DJ, Savage PJ, Bennett PH (1981) Diabetes incidence in Pima Indians: contributions of obesity and parental diabetes. Am J Epidemiol 113: 144-156

20. Zimmet P, Taft P, Guinea A, Guthrie W, Thoma K (1977) The high prevalence of diabetes on a Central Pacific island. Diabetologia 13: 111-115

21. Stern MP, Haffner SM (1988) Do anthropometric differences between Mexican-Americans and Non-Hispanic Whites explain ethnic differences in metabolic variables? Acta Med Scand 723 [Suppl]: 37-44

22. Haffner SM, Mitchell BD, Hazuda HP, Stern MP (1991) Greater influence of central distribution of adipose tissue on incidence of non-insulin-dependent diabetes in women than men. Am J Clin Nutr 53: 1312-1317

23. Iso H, Kiyama M, Naito Y et al. (1991) The relation of body fat distribution and body mass with haemoglobin $\mathrm{A}_{1 \mathrm{c}}$, blood pressure and blood lipids in urban Japanese men. Int J Epidemiol 20: $88-94$

24. Haffner SM, Stern MP, Hazuda HP, Rosenthal M, Knapp JA, Malina RM (1986) Role of obesity and fat distribution in non-in- 
sulin-dependent diabetes mellitus in Mexican Americans and Non-Hispanic Whites. Diabetes Care 9: 153-161

25. Ashwell M, Cole TJ, Dixon AK (1985) Obesity: new insight into the anthropometric classification of fat distribution shown by computed tomography. BMJ 290: 1692-1694

26. Seidell JC, Oosterlee A, Thijssen MAO et al. (1987) Assessment of intra-abdominal and subcutaneous abdominal fat: relation between anthropometry and computed tomography. Am J Clin Nutr 45: 7-13

27. Ferland M, Despres JP, Tremblay A et al. (1989) Assessment of adipose tissue distribution by computed axial tomography in obese women: association with body density and anthropometric measurements. Br J Nutr 61: 139-148

28. Haffner SM, Katz MS, Stern MP, Dunn JF (1988) The relationship of sex hormones to hyperinsulinemia and hyperglycemia. Metabolism 37: 683-688

29. Seidell JC, Cigolini M, Charzewska J et al. (1990) Androgenicity in relation to body fat distribution and metabolism in 38-year old women: the European fat distribution study. J Clin Epidemiol 43: 21-34

30. Seidell JC, Björntorp P, Sjöstrom L, Kvist H, Sannerstedt R (1990) Visceral fat accumulation in men is positively associated with insulin, glucose, and C-peptide levels, but negatively with testosterone levels. Metabolism 39: 897-901

31. Pasquali R, Casimirri F, Cantobelli $S$ et al. (1991) Effect of obesity and body fat distribution on sex hormones and insulin in men. Metabolism 40: 101-104

32. Reaven GM (1988) Role of insulin resistance in human disease. Diabetes 37: 1595-1607

33. Bolinder J, Kager L, Östman J, Arner P (1983) Differences at the receptor and post-receptor levels between human omental and subcutaneous adipose tissue in the action of insulin on lipolysis. Diabetes 32: 117-123

34. Richelsen B, Pedersen SB, Moller-Pedersen T, Bak JF (1991) Regional differences in triglyceride breakdown in human adipose tissue - effects of catecholamines, insulin and prostaglandin E2. Metab Clin Exp 40: 990-996

35. Taylor R, Ram P, Zimmet P, Raper LR, Ringrose H (1984) Physical activity and prevalence of diabetes in Melanesian and Indian men in Fiji. Diabetologia 27: 578-582

36. Laws A, Terry RB, Barrett-Connor E (1990) Behavioral covariates of waist-to-hip ratio in Rancho Bernardo. Am J Public Health 80:1358-1362

37. Mitrakou A, Kelley D, Mokan M et al. (1992) Role of reduced suppression of glucose production and diminished early insulin release in impaired glucose tolerance. N Engl J Med 326: 22-29

38. Yoshioka N, Kuzuya T, Matsuda A, Tanigushi M, Iwamoto Y (1988) Serum proinsulin levels at fasting and after oral glucose load in patients with type 2 (non-insulin-dependent) diabetes mellitus. Diabetologia 31: 355-360

39. Leahy JL, Bonner-Weir S, Weir GC (1992) Beta-cell dysfunction induced by chronic hyperglycemia: current ideas on mechanism of impaired glucose-induced insulin secretion. Diabetes Care 15: $442-455$

40. Hollenbeck C, Reaven GM (1987) Variations in insulin-stimulated glucose uptake in individuals with normal glucose tolerance. J Clin Endocrinol Metab 64: 1169-1173

41. Koivisto VA, Yki-Järvinen H, DeFronzo RA (1986) Physical training and insulin sensitivity. Diabetes Metab Rev 1: 445-481

Received: 6 March 1992

and in revised form: 21 April 1992

Dr. P.M. McKeigue

Department of Epidemiology and Population Sciences

London School of Hygiene and Tropical Medicine

Keppel Street

London WC1E 7HT

UK 